\title{
PERSEPSI SANTRI KELAS 1 MDTA YPIM MINAS TERHADAP EGIATAN BELAJAR ONLINE DI MASA PANDEMI
}

\author{
Nazhifah ${ }^{1}$, Sekar Sur Azizah ${ }^{2}$, Suci Rohimah" Ridzhand Rudli Hasian Hutabarat ${ }^{4}$, Rahman \\ Siddiq $^{5}$
}

1,2,3,4,5 Universitas Muhammadiyah Riau

Jalan Tuanku Tambusai, Pekanbaru 082286516051

\begin{abstract}
Abstrak:
Kondisi pandemi covid -19 berujung pada berubahnya berbagai aspek kehidupan terutama pendidikan. Pendidikan yang harus dijalankan melalui daring (online) baik ditingkat apapun mulai dari tingkat taman kanak - kanak hingga perguruan tinggi, termasuk tingkat Madrasah Diniyah Takmiliyah Awaliyah (MDTA) yang terfokus mengajarkan pendidikan Al-Qur'an dan pelajaran - pelajaran yang bernuansa islami. Pendidikan yang digalakkan oleh Kementrian Agama sebagai pelengkap kegiatan pendidikan di tingkat SD/MI/sederajat dimana para santri tidak sepenuhnya mendapatkan pengetahuan agama di sekolah dasar masing - masing juga mempunyai peran yang sangat kuat dalam mempersiapkan generasi yang memiliki jiwa religiulitas, intelektulaitas, dan humanitas. Hampir setahun pandemi melanda menghambat jalannya pendidikan hingga programbelajar online dirumah menjadi jalan yang digalakkan. Namun, kondisi belajar online yang harus ditempuh hingga saat ini menghadirkan berbagai persepsi juga pandangan dari para santri karena biasanya pembelajaran seperti ini harus totalitas dilakukan secara tatap muka langsung. Penelitian ini menggunakan teori Kognitivisme yang dikemukan oleh Jean Piaget, seorang pskolog Swiss. Metode Penelitian ini yaitu metode kualitatif persepsi yang teknik pengumpulan data menggunakan wawancara online terhadap narasumber berjumlah 5 orang, dimana narasumber merupakan santri dari kelas 1 MDTA YPIM Minas terhadap belajar online yang telah dilalui. Hasil Penelitian menunjukkan bahwa santri kelas 1 MDTA YPIM ada yang menyutujui program belajar online karena kondisi pandemi covid -19 dan harus menjaga kondisi tubuh, ada yang berpandangan biasa saja tanpa ada pengaruh, dan dari 5 narasumber terdapat 3 orang kurang menyukai belajar online dengan berbagai alasan dan salah satunya kurang produktif dan efektifnya proses belajar.
\end{abstract}

\section{Paris Langkis}

Vol.1 Nomor 2, Maret 2021 
Kata Kunci :Santri ; MDTA ; Belajar; Online ; Pandemi,

\begin{abstract}
:
The conditions of the Covid -19 pandemic have resulted in changes in various aspects of life, especially education. Education that must be carried out online (online) at any level, from kindergarten to tertiary level, includes the Madrasah Diniyah Takmiliyah Awaliyah (MDTA) level which focuses on teaching AlQur'an education and Islamic-nuanced lessons. The education promoted by the Ministry of Religion as a complement to educational activities at the SD / MI / equivalent level where students do not fully acquire religious knowledge in their respective primary schools also has a very strong role in preparing generations who have a spirit of religiosity, intellect, and humanity. Nearly a year the pandemic hit it hampering the course of education so that online learning programs at home became a way to be encouraged. However, the conditions of online learning that must be taken up to now present various perceptions as well as views from the students because usually learning like this must be done in totality face-to-face. This study uses the Cognitivism theory proposed by Jean Piaget, a Swiss psychologist. This research method is a qualitative method of perception in which data collection techniques use online interviews with 5 people, where the informants are students from grade 1 MDTA YPIM Minas towards online learning that has been passed. The results showed that there were MDTA YPIM grade 1 students who approved the online learning program because of the Covid-19 pandemic conditions and had to maintain their body condition, there were those who had an ordinary view without any influence, and of the 5 informants there were 3 people who disliked learning online for various reasons and one of them is less productive and effective learning process.
\end{abstract}

Keywords: Santri; MDTA; Learn; On line ; Pandemic,

\title{
A. PENDAHULUAN
}

"Mencerdaskan kehidupan bangsa" yang tercantum pada pembukaan UUD 1945 alinea ke 2 haruslah terus digalakkan dalam dunia pendidikan sebagai salah satu cara terkuat dalam menyokong majunya generasi Indonesia. Namun, pandemicovid-19 yang melanda dunia khususnya Indonesia mengharuskan tiap jenjang pendidikan melaksanakan kegiatan belajar online takterkecuali denganjenjang MDTA. Pembelajaran online adalahsistembelajar yang memungkinkanmelalui internet dan teknologi berbasis jaringan dan terbuka serta tersebar dengan menggunakan perangkat pedagogi (alat bantu pendidikan) untuk memfasilitasi pembentukan proses belajar dan mengetahui melalui aksi dan interaksi yang berarti (DabbaghdanRitlandd 2005:15).

\section{Paris Langkis}

Vol.1 Nomor 2, Maret 2021 
Kegiatan belajar online dapat diartikan bahwa parasan tri dituntut untuk belajar dengan media teknologi berupa laptop atau android. Kagiatan belajar online yang dilaksanakan selama pandemic covid -19 sesuai dengan keputusan Kementrian Pendidikan dan Kabudayaan (kemendikbud) yang menerbitkan surat edaran nomor 15 tahun2020 tentang Pedoman Penyelanggaraan Belajar Dari Rumah Dalam Masa Darurat Covid-19. Surat edaran ini memperkuat edaran kemendikbud sebelumnya yaitu nomor 4 tahun 2020 tentang Pelaksanaan Pendidikan Dalam Masa Darurat Covid-19.

Ada beberapa kelebihan dan kekurangan dalam kegiatan belajar online seperti kelebihannya pelajar mampu lebih menguasai dunia teknologi dan mengurangi tingkat GagapTeknologi (GapTek) di era modern yang berkembang pesat saat ini, lalu meningkatnya kreativitas pelajar, mampu lebih mandiri dan punya interaktivitas yang lebih baik, memperkuat daya ingat dan mampu belajar lebih santai dirumah untuk kondisi pandemic juga pelajar lebih senang menggunakan android. Lalu kekurangan nya sepert itingkat pemahaman yang lebih sulit dikarenakan penjelasan pembelajaran tidak sedetail tatap muka langsung, lalu kualitas jaringan daerah yang berbedabeda, orang tua tidak sepenuhnya mendampingi anak dalam kegiatan belajar online, dan bertambahnya kesempaatan anak untuk bermain game dengan memanfaatkan waktu belajar lain sebagainya.

Namun, beda lagi dengan kondisi kegiatan belajar di MDTA YPIM terkhusus kelas 1, kegiatan belajar online untuk daerah luar kota dengan kondisi ekonomi keluarga yang mayoritas menengah kebawah serta adanya pelajaran yang memiliki gangguan tersendiri jikadipelajari melalui via online dengan kata lain sebaiknya dilakukan secara tatap muka. Hal inimenghadirkanpersepsitersendiri di kalangansantri kelas 1 MDTA YPIM yang berusia 7 - 8 tahuntentangkegiatanbelajaronline yang harusdilakukanhinggawaktu yang ditentukan.

Teori yang digunakan pada persepsi santri terhadap belajar online di masa pandemi adalah Teori Kognitivisme. Teori ini mengutamakan dan memfokuskan proses belajar, Yang dikemukakan oleh Jean Piaget, seorang psikolog Swiss. Dimana menurut Muhibbin:2005 Teori kognitivitisme dalam arti luas yaitu kognisi merupakan perolahan penataan, pengunaa pengetahuan. Kognitvisme berasal dari kata Cognitionjuga knowing yang memmiliki arti mengetahui.

Teori ini juga menekankan terhadap berbagai situasi dalam proses belajar itu sendiri, dimana berkaitan dengan ingatan, daya pikir, emosional, kestabilan, keaktifan, produktivitas. Maka berbagai kondisi yang dialami juga akan mempengaruhi proses belajar itu sendiri yang mengakibatkan banyaknya pandangan ataupun pemkiran kritis dengan ilmu pengetahuan yang ada dan yang dirasakan, berbagai persepsi dengan proses belajar yang dirasakan akan hadir sesuai dengan kondisi yang dialami.

Persepsi adalah tentang hasil pikiran seseorang dari situasi tertentu juga dapat diartikan sebagai penafsiran suatu objek, yaitu peristiwa atau informasi dilandasi oleh pengalaman hidup seseorang yang melakukan penafsiran itu. (Rahmad, 2003:16). Daripersepsikitabisamelihatpandangansantrimengenaikegiatanbelajar online yang sedangdilaksanakansejakbulanMaret 2020.Tentupersepsisantri kelas 1 MDTA YPIM berbeda - beda, halinidipengaruhidariberbagaihalseperti lingkungansekitar, 
kondisiekonomikeluarga, matapelajaran yang tengah dipelajarihinggakomunikasi interpersonal pelajardengan guru melalui via online.

Berikut data matapelajarankelas 1 dengantingkatankesulitanbelajar via online sesuaihasilobservasidanwawancaradenganwalikelas 1 MDTA YPIM.

\begin{tabular}{|l|l|c|l|c|}
\hline No. & \multicolumn{1}{|c|}{ Mata pelajaran } & Mudah & Sedang & Sulit \\
\hline 1 & Al-Qur'an & & & $\bullet$ \\
\hline 2 & Hadist & & & $\bullet$ \\
\hline 3 & Aqidah & $\bullet$ & & \\
\hline 4 & Akhlak & $\bullet$ & & \\
\hline 5 & SejarahKebudayan Islam & $\bullet$ & & \\
\hline 6 & Bahasa Arab & & & $\bullet$ \\
\hline 7 & Hifzhil & & $\bullet$ & \\
\hline 8 & PraktekIbadah & & $\bullet$ & \\
\hline
\end{tabular}

- : : Titik tingkatan

Sumber :WaliKelas (Hj.Syafrina, S.Ag)

Dari data diatas menunjukkan bahwa masih banyak mata pelajaran yang mengalami tingkatan tersendiri dan menghadirkan berbagai persepsi santri. Oleh karena itu, berdasarkan uraian diatas peneliti tertarik untuk melakukan penelitian "Persepsi Santri Kelas 1 MDTA YPIM Minas Terhadap Kegiatan Belajar Online di Masa Pandemi”.

\section{B. KAJIAN TEORI}

1) Pengertian Santri MDTA

Santri adalah nama lain dari kata pelajar yang sering digunakan di sekolahberbasis islami baik tingkatan apapun. Biasanya santri sering digunakan di madrasah yang sering disebut dengan pondok pesantren. Namun Santri juga berlaku di tingkatmadrasah apapun .Santri juga bisa disebut sebagai para pelajar yang mendalami ilmu-ilmu agama dipesantren ataupun di sekolah yang islami baik para pelajartinggal di pondok maupun pulang setelah selesai waktu belajar.

"Dalam pandangan Nurcholish Madjid asal usul kata "Santri" dapat dilihat dari duapendapat. Pendapat pertama mengatakan bahwa "Santri" berasaldari kata "sastri", sebuah kata dari bahasa Sansekerta yang artinya melek huruf. Pendapat yang didasarkan atas kaumsantri kelas literary bagi orang Jawa yang berusahamendalami agamamelalui kitab-kitab bertulisan dan berbahasa Arabmenurut Nurcholish Madjid. Pendapat kedua mengatakan bahwa perkataan santri sesungguhnya berasal dari bahasaJawa, dari kata "cantrik" berarti seseorang yang selalu mengikuti seorangguru kemana guru tersebut pergi menetap."

Kata santri untuk pelajar laki - laki disebut santriwan, dan untuk perempuan Santriwati. Santri sering dijadikan sebagai role model gambaran generasi terbaik utuk negeri dalam kesungguhannya belajar baik dari tingkatan apapun, karena santri dikenal akan kedisiplinan yang luat, rasa hormat dan segan yang tinggi, juga adab yang sangat terjaga kepada siapapun.

Paris Langkis

Vol. 1 Nomor 2, Maret 2021 
MDTA adalah kepanjangan dari Madrasah Diniyah TakhmiliyahAwaliyah yang berarti menjadi tempat sekolah untuk Madrasah Diniyah setingkat SD/MI dimana siswa-siswi yang juga sedang bersekolah di tingkat Sekolah Dasar (SD). Dulunya dikenal dengan Madrasah Diniyah Awaliyah (MDA), namun sesuai dengan Peraturan Kementrian Agama Republik Indonesia Nomor 13 tahun 2014 diubah Menjadi MDTA .Biasanya masa pendidikan mandrasah terdiri 4 tahun setelah menjalankan masa pendidikan di Taman Pendidikan Alqur'an (TPA) selama 1 tahun atau sering dikenal dengan masa pra madrasah yangterfokus pada pembelajaran iqra'. "Madrasah Diniyah Takhmiliyah Awaliyah (MDTA) menurut buku pedoman penyelenggaraan Madrasah Diniyah Takmiliyah yang diterbitkan oleh kementrian Agama (Kemenag) merupakan Satuan pendidikan keagamaan bukan formal yang menyelenggarakan pendidikan kegamaan islam sebagai pelengkap pelajar SD/MI/ sederajat juga anak usia setingkat. Jenjang dasar yang ditempuh dalam kurun waktu 4 tahun dan 18 jam pelajaran seminggu.” Pendidikan Madrasah Diniyah Takhmiliyah Awaliyah pada dasarnya ialah pendidikan kepada masyarakat berusia dini dengan tujuan dalam rangka memberikan ilmu agama dengan kemampuan dasar kepada santri agar mampu mengembangkan diri juga bermanfaat bagi kehidupannya sebagaiinsan yang rabbani, muslim muslimah yang sholih - sholihah, dan menjadi generasi yang berbakti pada nusa bangsa dan negara. Begitu juga dengan Madrasah Diniyah Takhmiliyah Awaliyah Yayasan Perguruan Islam Mesjid (MDTA YPIM)di Kecamatan Minas, Kabupaten Siak, Provinsi Riau. Dengan jumlah jam belajar yang juga sesuai ketentua nkemenag yakni 18 jam pelajaran seminggu. Materi yang diajarkan meliputi: Fiqih,, Hadits, , Bahasa Arab, Alquran, Sejarah Kebeudayan Islam, Hifzhil, Praktek Ibadah, Aqidah danAkhlak. Dengan materi dan praktek yang diberikan juga dibimbing, tentunya para santri diharapkan mampu menguasai dan mengamalkan menjadi pribadi yang semakin religius.

Di MDTA YPIM juga sangat meyesuaikan jadwal para santri dengan jadwah belajar di Sekolah Dasar. Maka pembagian belajar di MDTA YPIM Minas ada dua, pertama waktu pagi yang dimulai dari 07:30 - 10:00 WIB, dan waktu sore dari 15:00 - 17:30 WIB . Jadwal yang padat tentu juga memiliki peran yang sangat besar dalam memajukan generasi yang bernilai religius, intelektualitas juga humanitas. Dalam menyelenggarakan pendidikan yang berbasis keagamaan Peran Madrasah Diniyah Takhmiliyah Awaliyah sangat berarti bagi masyarakat dan generasi sekitar, hal ini dikarenakan masih banyak anak - anak yang berada dilingkungan Peran Madrasah Diniyah Takhmiliyah Awaliyah tersebut tidak sepenuhnya mendapat pengetahuan agama di sekolah mereka masing-masing, karena Sebahagian besar dari mereka bersekolah di lembagapendidikan Umum yaitu di Sekolah Dasar Negeri.

Hadirnya Madrasah Diniyah TakhmiliyahAwaliyah juga sangat membantu para santri dalam mengenal, mengetahui, memahami serta mengamalkan tiap materi agama yang didapatkan yang barangkali tidak ada atau tidak selengkap di sekolah umum yaitu Sekolah Dasar yang juga para santri tapaki di dunia pendidikan.

Metode pendidikan yang dilakukan di MDTA YPIM juga dengan berbagai cara, metode belajar di kelas sesuai tingkatan yang ada hingga praktek yang dibimbing para guru,

Paris Langkis

Vol. 1 Nomor 2, Maret 2021 
seperti praktek wudhu, sholat, bacaan Iqra' dan Al-Qur-'an, doa harian, juga hafalan ayat - ayat $\mathrm{Al}$-Qur'an memberi pengaruh kuat bagi santri untuk terus mengamalkan dengan baik.

\section{2) Pengertian Belajar Online}

Belajar adalah proses menerima ilmu yang akan memberi pengembangan pola piikir yang kritis, interaksi fikiran dan daya kerja otak juga perubahan terhadap perilaku yang utama, hasi karya dan praktik yang sesuai denga materi yang didapat sebagai hasil dari pelajaran yang diterima.

"Learning is the procces by which an activity originates or changed through training procedures (wether in laboratory or in the natural environment) as distinguished from changes by factors not attributable to training (Hilgard dalam sanjaya:2007)."

Kata Online sering dimaknai dengan daring atau jaringan, jadi online merupakan kegiatan dan aktivitas apapunyang dilakukan melalui media elektronik yang terkoneksi dengan jaringan sehingga kegiatan ini selalu berhubungan dengan media atau tidak langsung bertatap muka.

"Dalam Badan Pengembangan dan Pembinaan Bahasa kementrian Pendidikan dan Kebudayaan dikatakan bahwa istilah online dipadankan dengan dalam jaringan yang lawan katanya offline atau luar jaringan dengan arti perangkat elektronik yang terhubung jaringan, sementara offline atau luar jaringan memilki arti tidak terhubung perangkat elektronik ke jarigan internet."

Belajar online sangat luas dikenal saat ini, bahkan seringkali diaplikasikan dalam dunia pendidikan yaitu belajar dari rumah dan dilaksanakan secara online (dalam jaringan) dengan media alektronik seperti android, dan aplikasi yang mendukung jalannya pendidikan secara video call yaitu Goggle Meet, Meeting Zoom, juga belajar online melalui Whatsaap group, Google Classroom dan sebagainya.

Belaja online mempunyai dampak positif dan dampak negatif tersendiri sesuai kondisi dan bagi generasi kedepannya, dimana para pelajar atau santri digalakkan untuk cepat memahami penggunaan teknologi dan membiasakan diri dalam sehari sering menggunakan Android dalam media pembelajaran.

Belajar online juga mempunyai tantangan tersendiri dalam menghadapinya, baik guru dan pelajar harus saling kontribusi yang baik, karena masih banyak juga saat ini masyarakat yang GapTek (Gagap Teknologi) sehingga terjadi banyak gangguan dalam proses belajar mengajar seperti kesulitan dalam mengoperasikan android,kurang memahami siste dari aplikasi pembelajaran dan gangguan sebagainya yang bersifat teknis dan sistem.

\section{3) Pengertian Pandemi}

\section{Paris Langkis}

Vol.1 Nomor 2, Maret 2021 
Pandemi sering diartikan dengan wabah ataupun penyakit yang menyebar luas, atau juga bersifat global menyerang banyak sekali masyaakat di banyak daerah bahkan bisa juga mendunia. Pandemi ini hadir dari suatu penyakit yang melihat titik penyebaran yang terjadi apakah sudah sangat meluas.

"Menurut Meriam - Webster yang juga menobatkan kata pandemi sangat tepat menjadi kata pemenang untuk kondisi saat ini, bahwa pandemi merupakan wabah penyakit yang mempengaruhi sebagian besar populasi dan terjadi di wilayah geografis yang luas (mencakup beberapa negara atau benua). Dengan akar kata yunani yaitu pan artinya semua dan demo yang berarti orang."

Organisasi Kesehatan Dunia secara resmi melabeli covid-19 sebagai pandemi, dimana kata pandemi ini berasal dari besarnya jumlah penyebaran wabah penyakit yang bernama covid -19, yang hadir sejak tahun 2019 dan menyebar ke wilayah negara Indonesia tahun 2020 diduga tepat pada tanggal 14 Februari. Covid - 19 merupakan penyakit yang menular disebabkan virus yang bernama corona, orang orang yang terkena virus ini akan mengalami gejala, baik gejala ringan hingga sedang, ada yang dapat pulih dengan isolasi mandiri tanpa perlu dirawat dirumah sakit, namun ada juga yang harus diisolasi sesuai fasilitas yang disediakan pemerintah .

Kasus covid- 19 setiap hari selalu meningkat drastis menjadikan kondisi ini haruslah sangat diperhatikan, maka sering disebut dengan masa pandemi, banyak aktivitas sehari - hari yang harus dipertimbangkan, bahkan berbagai aspek kehidupan seperti perekonomian, pendidikan, ibadah, kebudayaan dan berbagai aspek sangatlah terganggu dengan adanya pendemi ini. Banyak prosedur yang diubah dan digalakkan sesuai dengan protokoler kesehatan sebagai upaya meminimalisir angka orang yang terkena virus covid -19, dari banyaknya korban yang berjatuhan di kondisi ini, masyarakat harus terus menjalankan aktivitas di masa pandemi ini dengan berbagai cara yang meminimalisir untuk berjumpa atau mengadakan pertemuan langsung, baik itu dilakukan secara online atau dengan pertemuan yang jumlah orangnya terbatas, menjaga jarak, mencuci tangan, menggunakan masker atau face shield.

Kondisi pandemi banyak mengajarkan masyarakat diberbagai belahan dunia untuk terus memfokuskan dan menjaga kesehatan diri juga orang lain, memperkuat ibadah sesuai dengan agama serta kepercayaan masing - masing, juga untuk terus bersyukur atas apapun yang dimiliki saat ini.

\section{METODE PENELITIAN}

Metode yang digunakan dalam penelitian ini adalah Induktif Kualitatif dengan jenis penelitian wawancara. Wawancara adalah suatu penelitian yang langsung menanyakan pendapat kepada orang - orang yang berada dalam lingkup tersebut. Penelitian wawancara dilakukan untuk mengetahui pandangan juga persepsi dari santri kelas 1

\section{Paris Langkis}


MDTA YPIM terhadap belajar online yangtelak dilaksanakan selama masa pandemi di Kecamatan Minas, Kabupaten Siak, Provinsi Riau. Teknik analisis data, penulis menyajikan dengan pengumpulan data pendapat dan pandangan santri lalu menarik kesimpulan dari 5 orang yang telah diwawancarai.

\section{HASIL DAN PEMBAHASAN}

Peneliti melaksanakan wawancara juga observasi pada beberapa santri kelas 1 MDTA YPIM dengan tanggapan dan respon mengenai proses pembelajaran di masa pandemi pada hari Senin tanggal 25 Januari 2021. Wawancara di lakukan juga melalui online yaitu telepon Whatsapp dan terdiri dari 5 responden.

\section{Berdasarkan pengumpulan wawancara.}

\section{D.1 Pandangan adanya belajar online untuk kelas 1 MDTA YPIM di masa pandemi}

Dari 5 respoden yang telah diwawancarai tentang sub hasil dan pembahasan pertama.

Pada responden pertama yaituAbstract

The conditions of the Covid -19 pandemic have resulted in changes in various aspects of life, especially education. Education that must be carried out online (online) at any level, from kindergarten to tertiary level, includes the Madrasah DiniyahTakmiliyahAwaliyah (MDTA) level which focuses on teaching Al-Qur'an education and Islamic-nuanced lessons. The education promoted by the Ministry of Religion as a complement to educational activities at the SD / MI / equivalent level where students do not fully acquire religious knowledge in their respective primary schools also has a very strong role in preparing generations who have a spirit of religiosity, intellect, and humanity. Nearly a year the pandemic hit it hampering the course of education so that online learning programs at home became a way to be encouraged. However, the conditions of online learning that must be taken up to now present various perceptions as well as views from the students because usually learning like this must be done in totality face-to-face. This study uses the Cognitivism theory proposed by Jean Piaget, a Swiss psychologist. This research method is a qualitative method of perception in which data collection techniques use online interviews with 5 people, where the informants are students from grade 1 MDTA YPIM Minas towards online learning that has been passed. The results showed that there were MDTA YPIM grade 1 students who approved the online learning program because of the Covid-19 pandemic conditions and had to maintain their body condition, there were those who had an ordinary view without any influence, and of the 5 informants there were 3 people who disliked learning online for various reasons and one of them is less productive and effective learning process.

Keywords: Santri; MDTA; Learn ; On line ; Pandemic,, responden tidak menyukai pembelajaran online karena semakin menambah ketidakfahaman terhadap materi pembelajaran apalagi jika belajar Al-Qur'an, membutuhkan video call yag lebih lama, sementara jumlah santri kelas 1 MDTA sejumlah 30 orang. 
Menurut responden memang banyak sekali tempat atau wadah belajar, seperti Google Classroom, atau yang berbasis video yaitu meeting zoom dan Google meet. Tapi, rasanya berbeda jika tidak berjumpa dengan ibu guru dan belajar langsung, lebih cepat faham daripada belajar online.

Pada responden kedua yaitu NindyaRidanti, responden senang adanya kegiatan belajar online, agar lebih santai dirumah, dan terfokus menjaga kesehatan.Menurut responden di kondisi pandemi seperti ini, responden hanya dirumah saja sesuai pesan orang tua karena responden yang juga masih tergolong anak usia 8 tahun lebih rentan terkena dengan imunitas tubuh yang cepat berubah juga sebagai upaya meminimalisir korban di wabah yang tejadi saat ini yaitu Covid-19. Maka dari itu belajar online atau belajar dari rumah sesuai dengan apa yang diharapkan oleh responden kedua.

Pada responden ketiga yaitu AzizahNur, responden merasa biasa saja baik beajar online juga offline karena sama - sama mempunyai tugas sekolah atau sering disebut pr (Pekerjaan Rumah) yang tingkat sibuknya sama.

Pandangan responden mengatakan tidak ada kondisi yang berbeda, setiap hari harus terus belajar dan hanya libur di akhir pekan, jadi tidak masalah harus belajar dengan model apapun.

Pada responden keempat yaitu Salsabila Nadhifa, selama hampir 1 tahun belajar online responden kesulitan dengan belajar online dimasa pandemi karena harus berbagi Android dengan kakak dan adiknya, dikarenakan kondisi materi, tidak mampu harus membeli Android untuk respoonden.

Responden menyampaikan beruntung bu guru mampu memahami kondisi ini, jadi tidak terburu - buru jika ada tugas dan diberikan waktu pengumpulan lebih lama.

Namun, pandangan responden tetap kesulitan walau diberi keringanan, dimana responden tidak bisa update materi dengan segera, karena berbagi Android sering ketinggalan berbagai informasi untuk memahami materi atau melakukan praktek. Seperti praktek wudhu, sholat, setoran hafalan, percakapan dan pelafalan bahasa arab juga sebagainya.

Pada responden kelima yaituHaziqha Jazima Andini, responden mengatakan kurang menyukai pembelajaran mealalui online, selain kesulitan dalam pemahaman pelajaran yang harusnya diajarkan melalui tatap langsung juga karena tidak bisa berjumpa teman - teman dan mengaji bersama, responden merasa sepi dan kurang daya semangat dalam belajar, karena biasanya belajar bersama teman - teman,namun karena kondisi pandemi covid -19 hampir setahun tidak berjumpa lagi.

D.2 Pendapat untuk perkembangan kegiatan belajar online untuk kelas 1 MDTA YPIM di masa pandemi

Pada responden pertama yaituAlfiahHasanah, responden berpendapat sebaiknya untuk pelajaran seperti membaca Alqur'an dan pelajaran dengan tingkatan yang harus 
diajarkan langsung sesekali diadakan tatap muka dengan protokoler kesehatan yang ketat, dan alhamdulillah sekarang sudah dilaksanakan sebagai percobaan untuk persiapan pembelajaran kedepan.

Menurut responden dari banyaknya tempat atau wadah belajar, seperti Google Classroom, atau yang berbasis video yaitu meeting zoom dan Google meet yang bis ajuga dimanfaatkan dengan baik disaat online, namuntetap sebaiknya ada sekali alam sepekan untuk beljar offline agar tingkat kefahaman lebih baik daripada yangdidapat melalui online .

Pada responden kedua yaituNindyaRidanti, responden berpendapat jika kondisi pandemi covid-19 masih terus terjadi sebaiknya tetap diadakan dengan online, jika pun ada offline cukup dilakukan pertemua sekali atau dua kali dalam sepekan namun harus benar - benar dijaga protokoler kesehatan yang telahditetapkanoleh pemerintah, agar santri juga mampu memaksimalkanitsirahat dalam menjaga kesehatan dan imunitas tubuh di kondisi yang sangat mengkhawatirkan saat ini.

Responden jugasenang adanya kegiatan belajar online, agar lebih santai dirumah, dan terfokus menjaga kesehatan. Menurut responden di kondisi pandemi seperti ini, responden hanya dirumah saja sesuai pesan orang tua karena responden yang juga masih tergolong anak usia 8 tahun lebih rentan terkena dengan imunitas tubuh yang cepat berubah juga sebagai upaya meminimalisir korban di wabah yang tejadi saat ini yaitu Covid-19. Maka dari itu belajar online atau belajar dari rumah sesuai dan tidak masalah dengan apa yang diharapkan oleh responden kedua.

Pada responden ketiga yaitu AzizahNur, responden berpendapat lebih baik belajar offline atau tatap muka secara langsung, walau responden berpendapat sama aja, namun bedanya jarang sekali jumpa guru dan teman - teman yangg menjadi motivasi belajar bersama apalagi jika ada tugas madrasah.

Pada responden keempat yaituSalsabila Nadhifa, responden berpendapat kedepannya harus diusahakan untuk belajar secara tatap muka sesering mungkin, walau online juga mampu dilakukan, tapi bagi responden beserta teman - teman lainnya sekelas merasa kurang mampu menerima pelajaran secara online.

Responden menyampaikan walau beruntung bu guru mampu memahami kondisi ini, Namun, pandangan responden juga merasa tidak enak dengan para guru jika sering tidak memahami pelajaran daripada faham apalagi pelajaran yang lebih mudah difahami dengan praktik.

Pada responden kelima yaitu Haziqha Jazima Andini, responden menyarankanalangkah lebih baiknya belajar tatap muka saja, agar lebi teratur dan efektif, karena belajar online sangat tidak efektif, semangat belajar sangat turun dan lebih bermalas - malasan

Paris Langkis

Vol.1 Nomor 2, Maret 2021 
dirumah. Di kondisi seperti ini, semoga sekolah tatap muka tidak hanya jadi percobaan tapi tetap diterapkan selalu dengan protokoler kesehatan yang lengkap dan sesuai.

Responden merasa belajar tatap muka menjadi salah satu hadirnya lagi semangat belajar yang baik agar mendapatkan hasil belajar yang memuaskan juga mampu mengamalkan pelajaran dengan baik, memang sulit rasanya untuk kondisi seperti ini diadakan tatap muka, tapi responden berharap belajar tatap muka tetap digalakkan tanpa melupakan gerakan 3 M ( Mencuci tangan, Menggunakan masker, Menjaga Jarak).

\section{E. KESIMPULAN}

Persepsis antri kelas 1 MDTA YPIM Minas terhadap kegiatan belajar online di masa pandemi menggunakan teori kognivitivisme yang lebih memperhatikan proses belajar daripada hasil belajar, kondisi yang ada dan berbagia aspek sangatlah mempengaruhi proses belajar dimasa pandemic. Persepsi santri kelas 1 MDTA YPIM Minas terhadap belajar online didomanasi dengan kurang menyukai adanya proses belajar mengajar online dengan tanggapan belajar online menjadi proses pendidikan tidak efektif, kurang dapat memahami pelajaran dengan baik, bahkan pelajaran yang bersifat praktek seperti praktek wudhu dan sholat serta pelajaran membaca Al-Qur'an, lalu terlalu santai dalam belajar sehingga suka bermalas - malasan. Pandangan santri kelas1 MDTA YPIM Minas untuk kedepannya diharapkan penuh untuk selalu mengadakan proses belaja mengajar dengan tatap muka atau luar jaringan, di kondisi pandem isaat ini tetap bias dilakukan denga nmematuhi protokoler kesehatan yang telah ditetapkan pemerintah.

\section{F. SARAN DAN UCAPAN TERIMAKASIH}

Penulis mengucapkan terimakasih kepada pihak -pihak yang telah membantu dalam penelitian ini. Kemudian juga ucapan terimakasih diberikan kepada seluruh responden yang telah bersedia terlibat dan bekerja sama dalam penelitian ini. Saran dan kritik sangat membangun dibutuhkan dalam jurnal yang disajikan .

\section{DAFTAR PUSTAKA}

Covid-19 I Definition of Covid-19 by Merriam-Webster (internet).(cited 2020 July 18) Available from: https://kbbi.www.merriam-webster.com/dictionary/COVID-19

Dabbagh, N\& Bannan-Ritland, B. (2005). Online Learning: Concepts, Strategis. And Application. New Jersey: Pearson Education, Inc.

Moch. Jahid, "Penyelenggaraan Pendidikan Madrasah Takmiliyah" Jurnal MUADDIB, Vol. 06, No.01 (2016)

Muhibbin, Syah. 2005. Psikologi Pendidikan, Suatu Pendekatan Baru. Bandung: PT. Remaja Roskdarkarya

Sanjaya, Wina. 2006. Strategi Pembelajaran. Jakarta: Kencana Prenada Media Group 
Wahyuda, Syaiputra Meisa Diningrat "Desain Model Pembelajaran Online Sebagai Upaya Memfasilitasi Belajar di Tempat Kerja” Jurnal Pendidikan Terbuka dan Jarak Jauh, Vol. 20, No.1 (2019)

www.Badanbahasa.kemdikbud.go.id (Tentang padanan istilah online dan offline) Yasmadi, Modernisasi Pesantren: Kritik Nurcholish Madjid Terhadap Pendidikan Islam Tradisional ( Jakarta: Ciputat Press, 2005), 61 